\title{
Individual Factors Influencing Publication Productivity: The Case of the UniBest
}

\author{
Muthiah Rahimah* \\ Department of Management \\ Faculty Economics and Business, Universitas Indonesia \\ Jakarta, Indonesia \\ muthiah.r@ui.ac.id \\ *) Corresponding author: Muthiah Rahimah
}

\author{
Aryana Satrya \\ Department of Management \\ Faculty Economics and Business, Universitas Indonesia \\ Jakarta, Indonesia \\ aryana@ui.ac.id
}

\begin{abstract}
The objective of this research is to analyze factors which influence the publication productivity of academic staff in universities, including variables such as demographic characteristics and individual achievements. Publication productivity was measured based on the number of articles published in the last three years, namely 2015, 2016, and 2017. The study utilized a database of 588 associate professors and professors from a UniBest, one of leading university in Indonesia. The results show that there are five variables that significantly influence the publication productivity variable: faculty, gender, academic rank, degree, and the number of years doing higher level research.
\end{abstract}

Keywords - publication productivity, academic faculty, big data; individual achievements, demographic characteristics

\section{INTRODUCTION}

Education is an important criterion or aspect used to assess a nation's quality. The educational world is complex, especially the role of educators in supporting the success of the learning process.

At the higher education level, educators are referred to as the academic staff, having an important role in generating qualified graduates. Scholars widely concur that people demonstrating high performance provide a competitive advantage for an organization [1]. The academic faculty in all world-class universities have a several tasks and responsibilities, among others things includes teaching courses and publishing academic papers within their fields of study.

In science-based industries, the ability of academic faculty to write and publish a high qualified scientific papers have a direct impact on the excellence of organizational competitiveness [1]. Research publications from a university are the main indicator that determines the productivity of an academic faculty [2]. In previous research in Malaysia, a main criteria used to develop a research-based university is attaining research publications in journals that have a good impact factor and that attract external research funding [3].

The defining characteristic of such universities is their commitment toward academic activities that lead to the development of science and the discovery of new ideas. Accordingly, there is a significant growth in the quantity of published academic papers worldwide, consisting of improvements in the number of journals, journal space occupied, conference proceedings, and participation in book series [4]. The academic faculty, who play the role as scholars, are expected to give some scientific contribution through their published academic papers.

The study presented in this paper aims to identify whether demographic characteristics and individual achievements affect publication productivity of an academic faculty in the university, such that decision makers may identify the strategy and effort to improve research productivity in scientific development. Scientific publication in many fields present the current information to develop a better society, so the promotion of academic faculty is thoroughly based upon it [2].

Based on Scimago Journal and Country Rank [5] data in 2018, Indonesia ranks eleventh among Asiatic region countries with 75,220 documents and 72,146 citable documents. In the Southeast Asia region, Singapore, Malaysia, and Thailand outperformed Indonesia, ranked 6th, 8th, and 9th, respectively, with 265,452, 248,457, and 156,829 documents. Another bit of data was gleaned from Kementerian Riset Teknologi dan Pendidikan Tinggi Republik Indonesia [6] in the middle of 2018, where Indonesia produced 12,233 scientific publications indexed by Scopus among ASEAN countries, occupying second position after Malaysia's 12,492 but surpassing Singapore's by 9,543. The difference between Indonesia's and Malaysia's achievements has, therefore, been reduced significantly. This fact means that there has been tremendous progress for Indonesian publications.

\section{ANALYTICAL FRAMEWORK}

Research is one of the important points underlying university education, besides teaching and community service. Research consists of a series of ongoing investigative processes in finding facts, building insights, and other elements considered important in answering social issues [2].

There are only a couple of comparative and international studies that examine academic research generally [7]. Nevertheless, over the last few decades, considerable attention has been paid to the topic of university research productivity [8]. Such studies generally reveal that women write fewer scientific publications $[9,10]$ although there is some adjustment seen in gender inequality from time to time [8]. 
Some research highlights the performance factors of scientists in the same research field, an important one being academic rank or seniority in their research career paths [11]. Theoretically, the academic rank of scientists might reflect the level of research performance, where their higher rank presumably reflects their productivity as scientists doing research.

Kim, Wendel, and Twombly [12] aimed to test the relationship between the status of international faculty and productivity with the controlling influence of the organization [12]. It is important since research shows that broad career experience is not only influenced by individual factors, but also the ways of interaction with organization and interpreting organizational experience [13].

In terms of enhancing publication productivity between the academic faculty, there is some chance that, as analyzed by Kyvik and Aksnes [4] on their research, some hypotheses may be reached: (1) the current generation from the academic faculty has higher academic standards than the previous one; (2) the chance of publication of research articles, either in journals, books, or magazines, has been improved as the number of scholars increases; (3) the current research situation is much better than before, either in terms of findings, equipment, and the usage of information technology for communication and sharing information [4].

Based on previous research from Williamson and Cable [1] using two methods of measurement, namely: (1) based on the number of academic journal publications and (2) the number of national academy of management conference presentations [1]. The publication quantity in academic journals for each faculty member was gained by taking notes on the publication numbers that were published in premier management journals.

In accordance with the description above, based on problem and goal of this research, there are two modification models that will be used, which are the conceptual model of Teodorescu [7] and Hedjazi and Behravan [14]. To answer the aim of this research, the research productivity is measured as the number of publications and defined as the amount of article journal, conference proceedings, and chapters within an academic book (i.e., a book chapter) that has already been published by the respondent in the last three years [7]: 2015, 2016, and 2017

Based on scope of the problem of this research, through big data that already collected in the university, hence the modification of research conceptual model is seen in Figure 1. We could see in Figure 1, there are 2 (two) independent variables, which are individual achievement (consisting of "years at current institution" and "years in higher level") and demographic characteristics (consist of "academic rank," "gender," "age," "marital status," "faculty," and "degree"), and also 1 (one) dependent variable, which is publication productivity in the last three years, 2015 through 2017.

From the theoretical background, the hypotheses used in this research are as follows:

H1-a: Years at current institution has significant influence on the publication productivity.

H1-b: Years with a higher rank level has significant influence on the publication productivity.
H2-a: Academic rank has significant influence on the publication productivity.

H2-b: Gender has significant influence on the publication productivity.

H2-c: Age has significant influence on the publication productivity.

H2-d: Marital status has significant influence on the publication productivity.

H2-e: Faculty has significant influence on the publication productivity.

H2-f: Degree has significant influence on the publication productivity.



Fig. 1. Descriptive Statistics

\section{METHOD}

The design of this research is descriptive explanatory, which is a deep research concerning research productivity literature between the academic faculty, and also the accumulation of big data from one of the leading universities in Indonesia, UniBest. The collected data covers individual academic faculty data accordance with the scope of research with the permanent lecturer status, the number of years at their current institution through December 31, 2017, years in higher level that is calculated up to December 31, 2017, academic rank, gender, age, which were calculated up to December 31, 2017, marital status, faculty, and degree.

There are 588 academic faculty data that comprise fourteen faculties spread over the state university, with academic positions being associate professor and professor. Both positions are the highest rank in the academic career path in Indonesia. The academic faculty data and the number of publications during 2015, 2016, and 2017 which are in the institution database will be processed quantitatively on this research.

The operationalization of research variable may be seen in Table 1, which is a classification of type of variable and indicator that will be used. From the research by Hedjazi and Behravan [14], the academic rank used are professor, associate professor, assistant professor, and lecturer [14]. Nevertheless, in this study, we only used the two highest ranks as the academic rank indicator in Indonesia, which are professor and associate professor, since the publication 
improvement of scientific papers from those ranks are often used by the government to measure the university ranking.

TABLE I. THE OPERATIONALIZATION OF RESEARCH VARIABLE

\begin{tabular}{|c|c|c|}
\hline Variable(s) & Indicator(s) & $\begin{array}{c}\text { Operationalization of } \\
\text { Variable }\end{array}$ \\
\hline \multirow[t]{2}{*}{$\begin{array}{l}\text { Individual } \\
\text { Achievements }\end{array}$} & $\begin{array}{l}\text { Years at current } \\
\text { institution }\end{array}$ & $\begin{array}{l}\text { Years of service which } \\
\text { calculated commencing from } \\
\text { the first date until December } \\
31,2017\end{array}$ \\
\hline & $\begin{array}{l}\text { Years in higher } \\
\text { level }\end{array}$ & $\begin{array}{l}\text { Years of service which } \\
\text { calculated commencing from } \\
\text { occupying the last position } \\
\text { until December } 31,2017\end{array}$ \\
\hline \multirow[t]{6}{*}{$\begin{array}{l}\text { Demographic } \\
\text { Characteristics }\end{array}$} & Academic Rank & $\begin{array}{l}\text { Associate professor } \\
\text { Professor }\end{array}$ \\
\hline & Gender & $\begin{array}{l}\text { Male } \\
\text { Female }\end{array}$ \\
\hline & Age & $\begin{array}{l}\text { The age is calculated from the } \\
\text { individual date of birth until } \\
\text { December } 31,2017\end{array}$ \\
\hline & Marital Status & $\begin{array}{l}\text { Single } \\
\text { Married }\end{array}$ \\
\hline & Faculty & $\begin{array}{l}\text { Faculty of Economics and } \\
\text { Business } \\
\text { Faculty of Humanities } \\
\text { Faculty of Law } \\
\text { Faculty of Administrative } \\
\text { Science } \\
\text { Faculty of Social and Political } \\
\text { Science } \\
\text { Faculty of Psychology } \\
\text { Faculty of Medicine } \\
\text { Faculty of Dentistry } \\
\text { Faculty of Public Health } \\
\text { Faculty of Nursing } \\
\text { Faculty of Pharmacy } \\
\text { Faculty of Engineering } \\
\text { Faculty of Computer Science } \\
\text { Faculty of Mathematics and } \\
\text { Natural Sciences }\end{array}$ \\
\hline & Degree & $\begin{array}{l}\text { S-1 (bachelor's degree) } \\
\text { S-2 (master's degree) } \\
\text { S-3 (doctoral degree) }\end{array}$ \\
\hline $\begin{array}{l}\text { Publication } \\
\text { Productivity }\end{array}$ & & $\begin{array}{l}\text { The number of whole articles } \\
\text { published in the form of } \\
\text { journal, proceeding, or book } \\
\text { chapter in 2015, 2016, and } \\
2017\end{array}$ \\
\hline
\end{tabular}

The grouping of faculties on the faculty indicator are based on three university main cohort for scientific endeavor in Indonesia, with the classification number from 1 to 6 as the humanities cohort, numbers 7 to 11 as health science cohort, and numbers 12 to 14 as the natural science cohort.

Multivariate linear regression analysis used data processing, citing the methods in prior research [7, 14], using SPSS software as the data processing tools, through factors incorporated in two independent variables toward one dependent variable.

\section{RESULT AND DISCUSSION}

The first data processing is analysis descriptive frequencies based on faculty, gender, degree, and academic rank. One of the purposes of this analysis descriptive frequencies is to see the spread of respondent data, with individual unit analysis on each working unit in the university.

Out of 588 academic faculty from fourteen faculties, the Faculty of Engineering, had the largest number of associate professor and professors: 123 seasoned professors or $20.9 \%$. The Faculty of Engineering is included within the natural science cohort, which was followed by Faculty of Humanities with 60 seasoned professors or $10.2 \%$.

Regarding the gender indicator, based on 588 data, males dominated the associate professor and professor positions with 340 persons or $57.8 \%$-more than females. It is indicated that males have more interest in writing and researching than female.

Furthermore, the indicator of last attended degree, based on 588 observations, a doctoral degree is the highest educational level held by the associate professors and professors, namely 526 persons or $89.5 \%$, then followed by master's degree with 61 persons or $10.4 \%$. Hence, the higher level of someone's achievement the higher productivity in doing research at a higher level.

Lastly, the academic rank indicator, judged from the 588 observations, the number of associate professors working for the institution is greater than professors, namely 342 persons or $58.2 \%$. However, the margin is not much larger than a professor, namely 246 persons or $41.8 \%$.

Based on Table 2, there are five variables that influence significantly toward the publication productivity variable for three years, namely faculty, gender, academic rank, degree, and years in higher education, all of them were significant at the level less than 0.05. So, hypotheses 1-b, 2-a, 2-b, 2-e, and 2-f are accepted. Faculty, gender, academic rank, degree, and years in higher level has a significant influence on publication productivity.

TABLE II. MUlTIPLE LINEAR REGRESSION TEST RESUlTS

\begin{tabular}{|l|l|l|l|l|c|}
\hline \multirow{2}{*}{ Model } & \multicolumn{2}{|c|}{$\begin{array}{c}\text { Unstandardized } \\
\text { Coefficients }\end{array}$} & $\begin{array}{c}\text { Standardized } \\
\text { Coefficients }\end{array}$ & \multirow{2}{*}{ t } & \multirow{2}{*}{ Sig. } \\
\cline { 2 - 4 } & \multicolumn{1}{|c|}{$\boldsymbol{B}$} & $\begin{array}{c}\text { Std. } \\
\text { Error }\end{array}$ & Beta & & \\
\hline 1 (Constant) & - & 4.998 & & - & 0.056 \\
Faculty & 9.572 & 0.066 & 0.098 & 1.915 & $0.020^{* *}$ \\
Gender & 0.154 & 0.549 & 0.099 & 2.339 & $0.017^{* *}$ \\
Academic & 1.314 & 0.599 & 0.150 & 2.392 & \\
Rank & 1.990 & 0.864 & 0.127 & 3.321 & $0.001^{* * *}$ \\
Degree & 2.622 & 1.008 & 0.038 & 3.035 & \\
Marital Status & 0.944 & 0.091 & -0.026 & 0.936 & $0.003 * * *$ \\
Years & - & 0.065 & -0.123 & - & 0.350 \\
current & 0.022 & 0.094 & 0.018 & 0.248 & 0.805 \\
institution & - & & & - & \\
Years in higher & 0.173 & & & 2.651 & $0.008^{* * * *}$ \\
education & 0.017 & & & 0.177 & 0.860 \\
Age & & & & & \\
\hline
\end{tabular}

Source: SPSS data processing results

From the results of the regression, female academics with a doctorate who had just started her last position would be more productive in work. The importance of doctoral degree on productivity at work is in line with the study of Hedjazi \& Behravan [14]. However, the result of this research is different from various previous studies associated with the relation between gender and academic staff productivity. D'amico, Vermigli, \& Canetto [15] found that the level of women's productivity is lower than a men, especially at the 
professor rank [15]. Another study by Holliday, Jagsi, Wilson, Choi, Thomas, and Fuller [16] has the same results, that male published more papers than female [16]. Based on research by Misra, Lundquist, Holmes, and Agiomavritis [17], it is noted that woman have harder teaching load than men, so they put more time into teaching $[17,18]$. It was also found in research by Corley [19] that female scientists in the sample used indeed resulting less publication than male scientists and also showed that the differences between the level of publication for men and woman becomes insignificant when controlling for discipline, marital status, and years in higher education [19]. But in Indonesia, the teaching load is well-distributed among men and woman, so both men and woman predicted should have the same amount of time to write and publish scientific papers, beside still being involved in teaching.

Eagan and Garvey [20] researched the relationship between race, gender, and stress level with the faculty productivity. The sample that researched was a men and woman with fair-complexion and also a men and woman with colored skinned, where the publication productivity from the fair-complexion men and woman was slightly raised compared to the color-skinned men and woman, because of stress level from the fair-complexion men and women were subjected to less discrimination based on skin color or race [20]. The level of discrimination on race and gender in Indonesia has been reduced significantly, hence both men and woman from every race may work freely, and woman may increase their publication productivity.

The results of this research also illustrates that an academic that occupies the position of professor in the natural science faculties cohort, is estimated to be more productive doing a research and publishing scientific papers. This outcome is in line with previous research, showing a significant influence between academic rank on publication productivity, however it does not explain which cohort of science do the most research [14]. When referring to much previous research, the results of research ends up being contradicted, as if there were no significant influence of academic rank on publication productivity [21, 22]. It is also contradicted by the research by D'amico et al. [15] that professors located in smaller departments were more productive than those in medium or large departments [15]. Furthermore, the results of this research indicate that the professor position located in the faculties of natural science cohort, which include in the large department size, is estimated more productive than a smaller one.

From the previous research by Hedjazi and Behravan [14], there are three groupings of departmental types, e.g., College of Agricultural and Natural Resources, College of Aburaihan, and Faculty of Agriculture at TMU, where the result is College of Aburaihan has a most significant influence toward the publication productivity [14]. In this research, from three grouping of faculties, e.g., humanities cohort, health science cohort, and natural science cohort, the result shows that the academic faculty in the natural science cohort is more productive than others.

The three factors that do not have a significant influence on the publication productivity are age, marital status, and years at the current institution. In line with the previous research by Hedjazi and Behravan [14], there were no significant difference between younger or older associate professors and professors, or married or single status toward the level of publication productivity [14]. However, years at the current institution was not explained further in the previous research.

\section{CONCLUSION AND SUGGESTIONS}

The study show that publication productivity is affected by the individual achievements variable and demographics factors, including faculty, gender, academic rank, degree, and years in higher education. However, the measurement was based only on individual achievements and demographic characteristics variables, excluding other factors that influenced the number of scientific publications from academic staff in universities. Moreover, the research sample used only one state university; hence, results are not necessarily sufficient to generalize conclusions. Therefore, future research may assess other factors that affect the amount of research productivity of academic faculty in other institutions in Indonesia, such as institutional and leadership characteristics.

Considering the importance of research productivity in an educational-based organization, the head of a university has to periodically check on the academic faculty with the aim to improving publication productivity that has an serious impact on the competitive advantage of a university. If there is any research associated with publication productivity and external factors from the university's scope, it could be yet another factor that also affects research productivity of an academic faculty.

\section{REFERENCES}

[1] I. O. Williamson and D. M. Cable, "Predicting early career research productivity: The case of management faculty," Journal of Organizational Behaviour, vol. 24, pp. 25-44, 2003.

[2] B. Usang, A. Basil, and U. Lucy, "Academic staff research productivity: A study of Universities in South-South Zone of Nigeria," Academic Journals, vol. 2(5), pp. 103-108, 2007

[3] S. K. Dhillon, R. Ibrahim, and A. Selamat, "Factors associated with scholarly publication productivity among academic staff: Case of a Malaysian public university," Technology in Society, vol. 42, pp. 160-166, 2015

[4] S. Kyvik and D. W. Aksnes, "Explaining the increase in publication productivity among academic staff: A generational perspective," Studies in Higher Education, vol. 40(8), pp. 1438-1453, 2015.

[5] Scimago Institutions Rangkings, Scimago Journal \& Country Rank, 2018. https://www.scimagojr.com/countryrank.php)

[6] Kementerian Riset Teknologi dan Pendidikan Tinggi Republik Indonesia, Penghargaan SINTA Awards Tahun 2018, 2018. (online available at https://ristekdikti.go.id/siaran-pers/penghargaan-sintaawards-tahun-2018/)

[7] D. Teodorescu, "Correlates of faculty publication productivity: A cross-national analysis," Higher Education, vol. 39(2), pp. 201-222, 2000.

[8] L. J. Sax, L. S. Hagedorn, M. Arredondo, and F. A III. Dicrisi, "Faculty research productivity: Exploring the role of gender and family-related factors," Research in Higher Education, vol. 43(4), pp. 423-446, 2002.

[9] M. L. Bellas and R. K. Toutkoushian, "Faculty time allocations and research productivity: Gender, race and family effects," The Review of Higher Education, vol. 22, pp. 367-390, 1999.

[10] L. J. Sax, A. W. Astin, W. S. Korn, and S. K. Gilmartin, The American College Teacher: National Norms for the 1998-99 HERI Faculty Survey. Los Angeles: Higher Education Research Institute, 1999.

[11] G. Abramo, C. A. D'Angelo, and F. D. Costa, "Research productivity: Are higher academic ranks more productive than lower ones?" Scientometrics, vol. 88, pp. 915-928, 2011. 
[12] D. Kim, L. W. Wendel, and S. Twombly, "International faculty: Experiences of academic life and productivity in U.S. universities," The Journal of Higher Education, vol. 82(6), pp. 720-747, 2011.

[13] H. Dundar and D. R. Lewis, "Determinants of research productivity in higher education," Research in Higher Education, vol. 39(6), pp. 607631, 1998.

[14] Y. Hedjazi and J. Behravan, "Study of factors influencing research productivity of agriculture faculty members in Iran," Higher Education, vol. 62(5), pp. 635-647, 2011.

[15] R. D'amico, P. Vermigli, and S. S. Canetto, "Publication productivity and career advancement by female and male psychology faculty: The case of Italy," Journal of Diversity in Higher Education, vol. 4(3), pp. 175-184, 2011

[16] E. B. Holliday, R. Jagsi, L. D. Wilson, M. Choi, C. R. Thomas Jr, and C. D. Fuller, "Gender differences in publication productivity, academic position, career duration and funding among US academic radiation oncology faculty," Journal of the Association of American Medical Colleges, vol. 89(5), pp. 767-773, 2014.
[17] J. Misra, J. H. Lundquist, E. Holmes, and S. Agiomavritis, "The ivory ceiling of service work," Academe Online, vol. 97(1), 2011.

[18] J. Jackson, "The story is not in the numbers: Academic socialization and diversifying the faculty," National Women's Studies Association Journal, vol. 16(1), pp. 172-185, 2004.

[19] E. A. Corley, "How do career strategies, gender, and work environment affect faculty productivity levels in university-based science centers?" Review of Policy Research, vol. 22(5), pp. 637655, 2005.

[20] M. K. Eagan Jr. and J. C. Garvey, "Stressing out: Connecting race, gender, and stress with faculty productivity," The Journal of Higher Education, vol. 86(6), pp. 923-954, 2015.

[21] A. R. Babu and Y. P. Sing, "Determinants of research productivity," Scientometrics, vol. 43(3), pp. 309-329, 1998.

[22] J. W. Creswell and J. P. Bean, "Research output, socialization and the Biglan model," Research in Higher Education, vol. 15(1), pp. 69-91, 1981. 